\title{
Naming Cyanophyta/Cyanobacteria - a bacteriologist's view
}

\author{
Aharon OREN \\ Department of Plant and Environmental Sciences, Institute of Life Sciences, and the Moshe Shilo Minerva Center \\ for Marine Biogeochemistry, The Hebrew University of Jerusalem, Jerusalem 91904, Israel; tel.: +972-2- \\ 6584951,fax:+972-2-6584425,e-mail: orena@cc.huji.ac.il
}

\begin{abstract}
This paper provides information on the origin and the etymology of the names of genera of Cyanophyta/ Cyanobacteria in current use and on the way new names are formed under the provisions of the International Code of Botanical Nomenclature and the International Code of Nomenclature of Prokaryotes. Special emphasis is placed on the differences between the two Codes that should be taken into account when creating new names compatible both with the botanical and with the bacteriological nomenclature system, to support the ongoing efforts to harmonize the nomenclature of the Cyanophyta/Cyanobacteria under the two Codes.
\end{abstract}

Key words: Cyanobacteria, Cyanophyta, Halothece, International Code of Botanical Nomenclature, International Code of Nomenclature of Prokaryotes, Nostoc

\section{Introduction}

"The knowledge of classical Latin and Greek is permanently decreasing". Thus complained Hans TRÜPER (1999) in this exemplary essay on "How to name a prokaryote? Etymological considerations, proposals and practical advice in prokaryotic nomenclature". Issues relating to etymology, Latin, and Greek are equally relevant to the nomenclature of the Cyanophyta/Cyanobacteria which was not discussed in-depth by TRÜPER (1999, 2001).

With over 250 names of genera described (see http://www.cyanodb.cz/valid_genera), the cyanobacteria are a relatively large group of prokaryotes. For comparison, the current list of genera with standing in the prokaryote nomenclature (http://www.bacterio.cict.fr/ number.html\#total), a list that contains only very few cyanobacterial names, encompasses about 1900 names.

The history of some of the cyanobacterial names is much longer than the nomenclatural history of most other prokaryotes. When in 1875 Ferdinand CoHn classified bacteria in six genera, many cyanobacterial genera had already been named by botanists such as HANS CHRISTIAN Lyngbye (1782-1837), CARL Adoph Agardh (1785-1859), and others. Some scientific names of cyanobacteria in current use even predate
LinNaEus, as shown by the case of Nostoc discussed below.

This short essay was written with two purposes. The first is to provide those who work with Cyanophyta/Cyanobacteria some information about the origin and the etymology of their names. The question "What's in a name"1 often allows interesting insights into the nature of these organisms. An understanding of the ways names were given in the past is also highly relevant when suitable names should found to describe newly discovered genera and species. Table 1 therefore presents a glossary that contains most of the elements found in the generic names of Cyanophyta/Cyanobacteria. Unfortunately the authors who proposed the names seldom provided their etymology. Therefore guesswork was sometimes needed, and comments and corrections relating to this list are welcome. Some elements used in the names are derived from Latin, but Greek words dominate. Botanists who described all those genera in the past have made a particularly creative use of the Greek dictionary. I hope that the glossary will be helpful to those who deal with cyanobacterial names, so that the dictum "It was Greek to me" will not apply to students of cyanobacteria.

\footnotetext{
1 SHAKESPEARE, Romeo and Juliet

2 Shakespeare, Julius Caesar
} 
The second reason for presenting this information is the ongoing effort to harmonize the nomenclature of the Cyanophyta/Cyanobacteria under the two Codes: the International Code of Botanical Nomenclature (McNeILL et al. 2007) 'the Botanical Code', and the International Code of Nomenclature of Prokaryotes (formerly the International Code of Nomenclature of Bacteria) (LAPAGE et al. 1992) - 'the Bacteriological Code'. Although the provisions in both Codes for naming new genera and species are quite similar, minor differences exist, and these should be taken into account when creating new names compatible both to the 'botanical' and to the 'bacteriological' nomenclature system.

\section{The rules of the Codes}

Most genera and species of Cyanophyta/ Cyanobacteria have been named under the rules of the Botanical Code; see also CoMpère (2005) for valuable comments on the way names are formed under the provisions of this Code. Only a few generic names have been published under the provisions of the Bacteriological Code. Examples are Halospirulina, Planktotricoides, Prochlorothrix, and Rubidibacter (OREN \& Tindall 2005; Oren et al. 2009).

When comparing the rules of nomenclature there are a number of interesting differences between both Codes:

1. According to Principle I of the Botanical Code, "Botanical nomenclature is independent of zoological and bacteriological nomenclature". However, the formerly similar Principle 2 of the Bacteriological Code was modified in 1999, and now states that "The nomenclature of Prokaryotes is not independent of botanical and zoological nomenclature" (DE Vos \& TRÜPER 2000). Therefore it is still possible to use a generic name with standing in the prokaryote nomenclature to name a new genus of plants, including cyanobacteria, but the opposite is no longer allowed.

2. Under both Codes, scientific names of taxonomic groups are treated as Latin. Under the Bacteriological Code, a specific epithet must be treated in one of the three following ways: 1 . As an adjective that must agree in gender with the generic name, 2. As a substantive (noun) in apposition in the nominative case, 3. As a substantive (noun) in the genitive case (Rule 12c). Under the Botanical Code, the rules are less strict: "The epithet in the name of a species may be taken from any source whatever, and may even be composed arbitrarily" (Art. 23.2). The Bacteriological Code does not enable the formation of a specific epithet such as used in Microcystis ichthyoblabe (from Greek i $\chi \theta \dot{s} \varsigma=$ fish; $\beta \lambda \alpha \dot{\beta} \eta=$ damage), but under the Botanical Code such an epithet can be validly published, even if Recommendation 23A.3(a) suggests "To use Latin terminations insofar as possible".

3. Under the Bacteriological Code, the derivation (etymology) of a new name must be given (Rule 27.2(b) as modified in 1999) (DE Vos \& TRÜPER 2000). Under the Botanical Code, the specification of the etymology of the new name is a recommendation only: "The etymology of new names or of epithets in new names should be given, especially when their meaning is not obvious" (Recommendation 60H.1).

4. Use of hyphens in specific epithets is not allowed under the rules of the Bacteriological Code. "If an epithet has been hyphenated, its parts should be joined. The name retains its validity and standing in nomenclature" (Rule 12a). Under the Botanical Code, the use of the hyphen is allowed, both in generic names (Article 20.3) and in specific epithets (Article 23.1; see also Article 60.9). Therefore names containing a hyphen such as Anabaena flosaquae and Dolichospermum torques-reginae [torquis-reginae would be grammatically preferable!] are allowed under the Botanical Code. Recommendation 23A.3(d) states that authors should avoid creating specific epithets formed of two or more hyphenated words, and recommendation 23A.3(b) warns against the creation of epithets that are very long and difficult to pronounce in Latin. Not all authors, however, have followed these recommendations, as the example of Coelosphaerium evidenter-marginatum shows (Azevedo \& Sant'Anna 1999).

Diacritical signs are not allowed in genus and species names under both Codes (Rule 64 of the Bacteriological Code; Art. 60.6 of the Botanical Code). The name Chamaesiphon komárekii (RotT 2008) was thus created in violation of the regulations, and should be corrected to Chamaesiphon komarekii. 
Overall the rules of the Botanical Code allow more ways to create new generic names and specific epithets than does the Bacteriogical Code. In view of the attempts to harmonize the nomenclature of the Cyanophyta/Cyanobacteria under both Codes, it is recommended that new names to be added in the future should be compatible with the provisions of both Codes.

\section{The case of Halothece californica}

In view of the above considerations, the case of the description of Halothece californica (MARGHERI et al. 2008) is to some extent a missed opportunity. The paper intended to provide a description of a new genus and species in a form that should be compatible first of all with the requirements of the Botanical Code, but with the Bacteriological Code as well. However, Principle 3 of Bacteriological Code states that "The scientific names of all taxa are Latin or latinized words treated as Latin regardless of their origin" (see also Rule 6), and Principle V of the Botanical Code was formulated similarly. Even if the Latin noun theca (a case, a box, a chest) was derived from the Greek noun $\theta \dot{\eta} \kappa \eta$, the Latin form should be used, and the correct genus name under both codes should therefore be Halotheca (etymology: ha.lo.the'ca; Gr. fem. n. hals, halos, salt; L. fem. n. theca, box [or Gr. fem. n. thece, to comply with Recommendation 6(3) of the Bacteriological Code and Recommendation 20A.1.(d) of the Botanical Code]; N.L. fem. n. Halotheca, salt box) (OreN 2009a). Moreover, according to current practice in prokaryote nomenclature, new 'geographical' names are formed with the ending -ensis (masc., fem.) or-ense (neut.) (TRÜPER 1999), and thus the preferred specific epithet is californiensis (ca.li.for.ni.en'sis; N.L. fem. adj. californiensis, pertaining to Baja California Sur, Mexico, where the nomenclatural type was isolated).

\section{Genera of Cyanophyta/Cyanobacteria named to honor famous scientists}

As customary also for other groups of plants, and in the bacteriological nomenclature as well, certain generic names and specific epithets in the cyanobacterial nomenclature honor colleagues, both in the past and in the present, who have made important contributions to our knowledge in the field. Thus we have genera such as Borzia and Borzinema (honoring ANTONIO BoRZI, 1852-1921), Geitleria and Geitlerinema (LothAR GeITLER, 1899-1990), Gomontiella (MAURICE Gomont, 1839-1909), Jaaginema (Отто JAAG, 1900-1978), Lemmermanniella (ERNST JOHANN LEMMERMANN, 1867-1915), Lyngbya and Leptolyngbya (Hans Christian Lyngbye, 1782-1837), Stanieria (Roger Stanier, 1916-1982), and others.

Undoubtedly there are more distinguished colleagues who have contributed much to the taxonomy of the Cyanophyta/Cyanobacteria and deserve to be honored with a name of a cyanobacterial genus. However, this is not always simple. For example: in the cases of FrIEDRICH KütZING (1807-1893) and CARL Adolph AgardH (1785-1859), Kuetzingia is already a rhodophyte genus, but "Kuetzingiella" can still be used; the name Agardhia apparently has been already used for more than one botanical taxon (see the Index Nominum Genericorum - A compilation of generic names published for organisms covered by the International Code of Botanical Nomenclature; http://botany.si.edu/ing/). The generic name Komarekia (an illegitimate substitute name for Hofmania) was given to a member of the Chlorophyceae to honor JIŘI KoMÁREK (FotT 1981), but "Komarekiella" may still be available.

To honor Ferdinand CoHn (1828-1898), who was the first to recognize the affiliation of the Cyanophyceae with the bacteria, with a new cyanobacterial genus name will be more complicated. Cohnia is already a genus of angiosperm plants, and Cohnella is an endosporeforming Gram-positive heterotrophic prokaryote. Principle I of the Botanical Code states that "Botanical nomenclature is independent of zoological and bacteriological nomenclature", so that formally the name Cohnella can still be proposed. However, this would create a homonym, which could lead to considerable confusion in the future. A remaining option is "Ferdinandcohnia" (compare Elizabethkingia, a genus name with standing in the prokaryote nomenclature). Finding a name for a cyanobacterial genus to honor the late Imre Friedmann (1921-2007) (OREN 2009b) will also be problematic. Friedmannia is already a member of the Chlorophyceae, and Friedmanniella is a heterotrophic prokaryote belonging to the Actinobacteria.

When creating names that should obtain standing both in the botanical and in the prokaryote nomenclature, it should be remembered that the 
Botanical Code allows the creation of composite names such as Borzinema, Geitleribactron etc., but Appendix 9 of the Bacteriological Code (TRÜPER \& EuZÉBY 2009) states only two ways to form a generic name from a personal name, either directly or as a diminutive; both are always in the feminine gender. Still, the Code does not forbid proposing compound nouns based on personal names, and two such names were added in 2009: Gordonibacter and Rummelliibacillus.

\section{The slimy world of cyanobacterial nomen- clature}

Many cyanobacteria excrete polysaccharide slimes, and this property is expressed in many generic names and specific epithets. The element 'gloeo' or 'gloea' (Gr. $\gamma \lambda$ otó $\varsigma$ gum, resin, oil) is found in the genus names Gloeothece, Gloeotrichia, Chlorogloea, and Chondrogloea. We further find Blennothrix (Gr. $\beta \lambda \varepsilon v v o ́ \varsigma=$ slime), Lithomyxa and Myxosarcina (Gr. $\mu v ́ \xi \alpha=$ discharge from the nose), and Hydrocoleum glutinosum (L. glutinosus $=$ viscous, sticky).

The most interesting 'slimy' generic name is undoubtedly Nostoc. The etymology of this name was disclosed in a delightful essay by PотTs (1997). The name predates the establishment of binomial nomenclature by LinNAEUS, and can be attributed to the $16^{\text {th }}$ century Swiss scientist, alchemist and philosopher Aureolus Philippus Theophrastus Bombastus von Hohenheim (14931541), better known under the name PARACELSUS. The original spelling is Nostoch, and this word was most probably derived from a combination of the Old English 'Nosthryl' and the German 'Nasenloch', two words that mean exactly the same: nostril. The name Nostoc soon became generally accepted, and the genus Nostoc became the type of the family Nostocaceae (BORNET \& Flahault, 1886-1888). The name is a typical case of a generic name composed in an arbitrary manner (Article 20.1 of the Botanical Code).

We also find the name in the nomenclature of non-photosynthetic prokaryotes in Leuconostoc (with the etymology: Gr. adj. leukos, clear, light; N.L. neut. n. Nostoc, algal generic name; N.L. neut. n. Leuconostoc, colorless nostoc) (see http:// www.bacterio.cict.fr/l/leuconostoc.html). The name was given to a genus of dextran-producing lactic acid bacteria in 1878, and was included in the Approved Lists of Bacterial Names (SKERMAN et al. 1980). Based on Rule 10a ("The name of a genus ... is treated as a Latin substantive"), it is no longer possible to create a name such as Nostoc under the rules of the Bacteriological Code, unless a Latin ending will be added.

Based on Article 20.1 of the Botanical Code, there is no problem with the newly proposed generic name Desmoc (Hrouzek et al. 2010), a combination of Gr. $\delta \varepsilon \dot{\sigma} \sigma \rho \varsigma=$ band, binding material, and part of the last syllable of 'Nasenloch' used nearly five hundred years ago to coin the name Nostoc. However, to the opinion of the author the name does not sound very elegant. Moreover, in a time attempts are made to harmonize the treatment of the nomenclature of the Cyanophyta/Cyanobacteria under both Codes, it is to be recommended that newly formed generic names should meet the standards not only of the Botanical Code, but also of Rule 10a and the other provisions of the Bacteriological Code, and that information on the etymology of the newly proposed names should be provided as well.

\section{Final comments}

This short essay shows that there are quite a number of interesting, and generally little known, features in the nomenclature of the Cyanophyta/ Cyanobacteria. Scientists who work with these prokaryotes rarely realize the source of the names of the organisms studied. Still, an understanding of the nomenclature (ideally backed up by some basic knowledge of Latin and Greek) can be helpful and provide an insight into the nature of the taxa. An in-depth understanding of the ways scientific names are formed and validly published is essential for those who wish to describe new genera and species.

Although the Botanical Code and the Bacteriological Code both use the binomial system that treats names of taxa as Latin words, there are minor differences between the two Codes. Attempts toward the harmonization of the treatment of Cyanophyta/Cyanobacteria under the two Codes are underway. Nomenclature matters are not the greatest problem here. Much more important are issues relating to the nature of the type material and to central registration and indexing of validly published names (OREN \& Tindall 2005; Oren et al. 2009). Based on Art. 45.4 of the Botanical Code, names of cyanobacteria validly published under the Rules of the Bacteriological 
Code are considered to be validly published also based on the requirements of the Botanical Code. If in the future the International Committee on Systematics of Prokaryotes, the body governing the International Code of Nomenclature of Prokaryotes (the Bacteriological Code), will be able to reciprocate this Art. 45(4), it will appear that quite a few names in current use are not in agreement with the way names are formed under that Code. Therefore it is recommended, when creating names of new genera and species, to use names compatible with both Codes.

\section{Acknowledgments}

I am grateful to the late E. Imre Friedmann for donating his marvelous collection of phycology books to the Jewish National and University Library, Jeruasalem, thus giving me access to the original editions of the publications by Agardh, Bornet \& Flahault, Cohn, Gomont, Hansgirg, Kützing, Lyngbye, Nägeli, Thuret and others which I consulted during the preparation of this paper.

\section{References}

Azevedo, M.T. de P. \& SAnT'Anna, C.L. (1999): Coelosphaerium evidenter-marginatum, a new planktonic species of Cyanophyceae/ Cyanobacteria from São Paulo State, Southeastern Brazil. - Algological Studies 94: $35-43$.

Bornet, E. \& Flahault, C. (1886-1888): Révision des Nostocacées héterocystées. - Ann. Sc. Nat. Bot., sér 7, 3: 323-381 (1886); 4: 343-373 (1886); 5: 51-129 (1887); 7: 177-262 (1888).

COMPÈre, P. (2005): The nomenclature of the Cyanophyta under the Botanical Code. Algological Studies 117: 31-37.

De Vos, P. \& Trüper, H.G. (2000): Judicial Commission of the International Committee on Systematic Bacteriology. IXth International (IUMS) Congress of Bacteriology and Applied Microbiology. Minutes of the meetings, 14, 15 and 18 August 1999, Sydney, Australia. - International Journal of Systematic and Evolutionary Microbiology 50: 2239-2244.

Fotт, B. 1981: Nomenklatorische Änderungen bei einigen Chlorokokkalalgen. - Preslia 53: 1-7.

Hrouzek, P., Mugnai, M.A., LukeŠová, A., Mascalchi, C., Turicchia, S., Komárek, J. \& Ventura, S. (2010): The genus Nostoc: a polyphyletic assemblage of filamentous cyanobacteria with primitive morphological characters. - In: KAŠTOVSKÝ, J. \& HAUER, T. (eds): Abstracts of the $18^{\text {th }}$ Symposium of the International
Association for Cyanophyte Research. - p. 20, České Budějovice.

Lapage, S.P., Sneath, P.H.A., Lessel, E.F., Skerman, V.B.D., Seeliger, H.P.R. \& Clark, W.A. (eds.) (1992): International Code of Nomenclature of Bacteria (1990 Revision). Bacteriological Code. - 189 pp., American Society for Microbiology, Washington DC.

Margheri, M.C., Ventura, S., Kaštovský, J. \& KomÁreK, J. (2008): The taxonomic validation of the cyanobacterial genus Halothece. Phycologia 47: 477-486.

McNeill, J., Barrie, F.R., Burdet, H.M., Demoulin, V., Hawksworth, D.L., Marhold, K., Nicolson, D.H., Prado, J., Silva, P.C., Skog, J.E., Wiersema, J.H. \& Turland, N.J. (editors and compilers) (2007): International Code of Botanical Nomenclature (Vienna Code) adopted by the Seventeenth International Botanical Congress Vienna, Austria, July 2005. - 568 pp., Gantner, Ruggell.

Oren, A. (2009a): Commentary - Problems associated with the taxonomic validation of the cyanobacterial genus Halothece by Margheri et al. 2008, Phycologia 47: 477-486. - Phycologia 48: 313-314.

Oren, A. (2009b): E. Imre Friedmann - 1921-2007. Algological Studies 130: 13-16.

Oren, A. \& Tindall, B.J. (2005): Nomenclature of the cyanophyta/cyanobacteria/cyanoprokaryotes under the International Code of Nomenclature of Prokaryotes. - Algological Studies 117: 3952.

Oren, A., Komárek, J. \& Hoffmann, L. (2009): NomenclatureoftheCyanophyta/Cyanobacteria/ Cyanoprokaryotes - what has happened since IAC Luxembourg? - Algological Studies 130: 129-144.

PotTs, M. (1997): Etymology of the genus name Nostoc (Cyanobacteria). - International Journal of Systematic Bacteriology 47: 584.

Rotт, E. (2008): Chamaesiphon komárekii species nova, a new benthic freshwater chroococcalean species (Cyanophyta/ Cyanobacteria) from western coniferous forest streams in British Columbia, Canada. - Algological Studies 126: 37-46.

Skerman, V.B.D., McGowan, V. \& Sneath, P.H.A. (1980): Approved lists of bacterial names. International Journal of Systematic Bacteriology 30: 225-420.

TRÜPER, H.G. (1999): How to name a prokaryote? Etymological considerations, proposals and practical advice in prokaryotic nomenclature. FEMS Microbiology Reviews 23: 231-249.

TRÜPER, H.G. (2001): Etymology in nomenclature of Procaryotes. - In: Boone, D.R.; Castenholz, R.W.; Garrity, G.M. (eds.): Bergey's Manual 
of Systematic Bacteriology, $2^{\text {nd }}$ ed., vol. I. - pp. 89-99, Springer, New York.

TRÜPER, H.G. \& EuZÉBY, J.P. (2009): International Code of Nomenclature of Prokaryotes. Appendix 9: orthography. - International Journal of Systematic and Evolutionary Microbiology 59: 2107-2113.

Table 1. A (non-exhaustive) list of word elements found in genus names of Cyanophyta/Cyanobacteria, based on the list given in http://www.cyanodb.cz/valid_genera. (Gr.) = Greek; (L.) = Latin. Elements derived from names of persons are not listed.

\begin{tabular}{|c|c|}
\hline \multicolumn{2}{|l|}{$\mathbf{A}$} \\
\hline 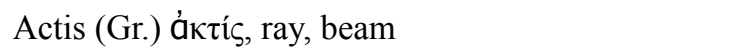 & Arbor (L.) arbor, tree \\
\hline Aggregatum (L.) aggrego, join together & Arthro- (Gr.) á $\rho \theta \rho o v$, a joint \\
\hline 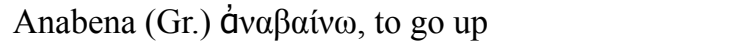 & 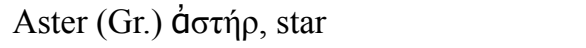 \\
\hline Aphano- (Gr.) á $\varphi \alpha v \eta ́ \varsigma$, unseen & 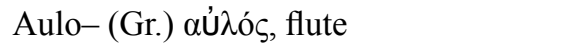 \\
\hline \multicolumn{2}{|l|}{ Aphanizo-(Gr.) á $\varphi \alpha v i ́ \zeta \omega$, to hide, to make unseen } \\
\hline \multicolumn{2}{|l|}{ B } \\
\hline 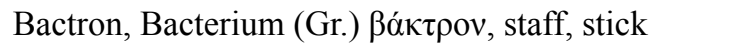 & Botrys (Gr.) ßó $\tau \rho v \varsigma$, bunch of grapes \\
\hline Bacula (L.) bacula, small berry & 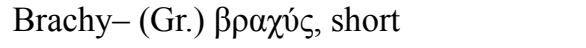 \\
\hline Blenno- (Gr.) $\beta \lambda \varepsilon v v o ́ \varsigma$, slime & Byrsa (Gr.) $\beta u ́ \rho \sigma \alpha$, hide, skin \\
\hline \multicolumn{2}{|l|}{$\mathbf{C}$} \\
\hline 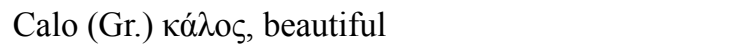 & 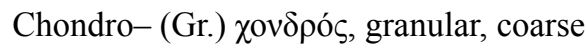 \\
\hline 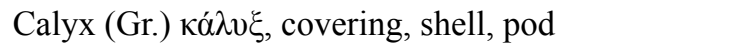 & 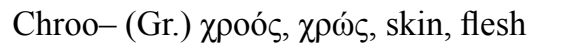 \\
\hline Camptylo- (Gr.) $\kappa \alpha \mu \pi v ́ \lambda o \varsigma$, bent, curved & Cladus (Gr.) $\kappa \lambda \alpha ́ \delta \delta \varsigma$, branch \\
\hline Capsa (L.) capsa, case, receptacle & Clast- (Gr.) $\kappa \lambda \alpha \sigma \tau o ́ \varsigma$, broken in pieces \\
\hline Carpella (Gr.) кá $\rho \pi о \varsigma$, fruit & Coelo-(Gr.) кóı $\lambda$ os, empty \\
\hline Caryo-(Gr.) кápvov, a nut & Coleus, Coleum (Gr.) ко $\lambda \varepsilon o ́ v$, sheath \\
\hline Catella (L.) catella, light chain & Coccus (Gr.) ко́кко, grain, seed \\
\hline Catena (L.) catena, chain &  \\
\hline Cavum (L.) cavum, hole & Crinis (L.) crinis, lock of hair, tress \\
\hline 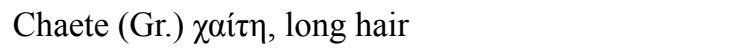 & 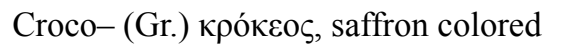 \\
\hline Chamae-(Gr.) $\chi \alpha \mu \alpha i$, on the ground & Cuspi- (L.) cuspis, sharp point, tip \\
\hline Chlamy-(Gr.) $\chi \lambda \alpha \mu \nu$ s, mantle & 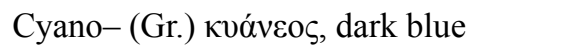 \\
\hline 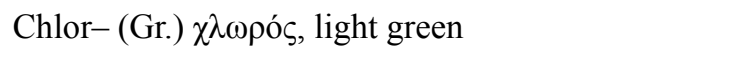 & 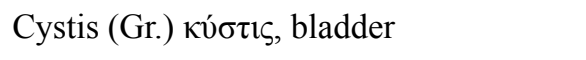 \\
\hline \multicolumn{2}{|l|}{ D } \\
\hline Dasy-(Gr.) $\delta \alpha \sigma u ́ \varsigma$, hairy & 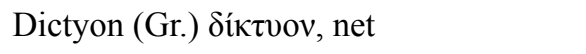 \\
\hline Derma (Gr.) $\delta \varepsilon ́ \rho \mu \alpha$, hide & 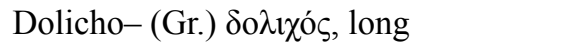 \\
\hline $\begin{array}{l}\text { Desmium, Desmo- (Gr.) } \delta \varepsilon ́ \sigma \mu o \varsigma, \text { band, binding } \\
\text { material }\end{array}$ & 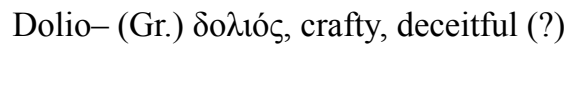 \\
\hline \multicolumn{2}{|l|}{ Dicho- $(\mathrm{Gr}.) \delta^{\prime} \chi \eta$, in two } \\
\hline \multicolumn{2}{|l|}{$\mathbf{E}$} \\
\hline Epi- (Gr.) غ̇ंí, upon, on & Ento- (Gr.) Évtós, inside, within \\
\hline  & $\mathrm{Eu}-(\mathrm{Gr}.) \varepsilon \cup \dot{\text {, well }}$ \\
\hline
\end{tabular}




\section{$\mathbf{F}$}

Fasciculus (L.) fasciculus, bundle, parcel

\section{G}

Gemino-(L.) geminus, twin

Glauco-(Gr.) $\gamma \lambda \alpha v \kappa o ́ s$, blue-green

Gloeo-, Gloea- (Gr.) $\gamma \lambda$ oı́ $\varsigma$, gum, resin, oil

\section{H}

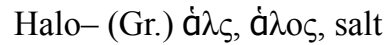

Hapalo- (Gr.) à $\pi \alpha \lambda o ́ \varsigma$, tender

Herpyzo- (Gr.) $\dot{\varepsilon} \rho \pi v ́ \zeta \omega$, to creep, to crawl

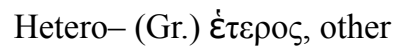

\section{I}

Is(o)- (Gr.) íoos, equal

\section{K}

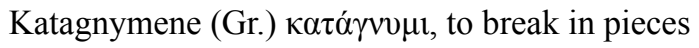
Kybus (Gr.) кúßos, cube

\section{$\mathbf{L}$}

Lepto-(Gr.) $\lambda \varepsilon \pi \tau o ́ s$, fine, small

Limno-(Gr.) $\lambda i ́ \mu v \eta$, pool of water, lake

\section{M}

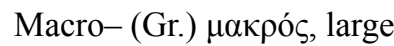

Mastigo-(Gr.) $\mu \alpha \sigma \tau$ - ${ }^{\circ} \omega$, to whip, to flog

Merismo-(Gr.) $\mu \varepsilon \rho ı \mu$ ós, partition, division

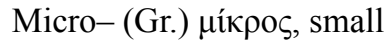

\section{$\mathbf{N}$}

Nema (Gr.) vท́ $\mu \alpha$, thread

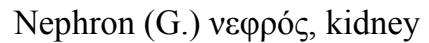

\section{$\mathbf{O}$}

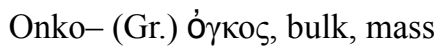

\section{$\mathbf{P}$}

Pannus (L.) pannus, piece of cloth, rag Para- (Gr.) $\pi \alpha \rho \alpha ́$, from beside, alongside Pedia (Gr.) $\pi \varepsilon \delta$ íov, plain

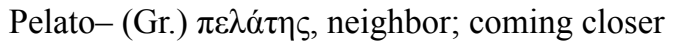

Phanon (Gr.) $\varphi \alpha v o ́ \varsigma$, light, bright

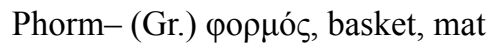

Physa- (Gr.) $\varphi v \sigma \alpha$, wind, air bubble

Placa (Gr.) $\pi \lambda \alpha \dot{\xi} \xi, \pi \lambda \alpha \kappa o ́ \varsigma$, flat surface, plain

Plankto- from (Gr.) $\pi \lambda \alpha ́ v o \zeta$, wandering

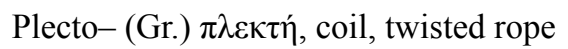

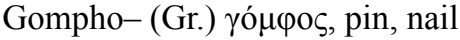

Granis (L.) granum, seed

Homeo-(Gr.) Ónotos, like, resembling

Hormo-, Hormato- (Gr.) ó $\rho \mu \mathrm{s}$, chain, necklace

Hydro- (Gr.) U่ $\omega \rho \rho$, water

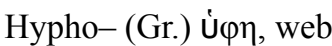

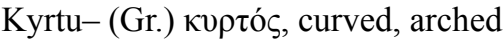

Lith(o)- (Gr.) $\lambda i \operatorname{\theta os}$, stone

Moron (Gr.) $\mu \omega \rho o ́ s$, sluggish

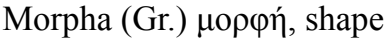

Мухо-, Муха (Gr.) $\mu$ $\xi \alpha$, discharge from the nose

Nodu-(L.) nodus, knot

Oscilla-(L.) oscillum, swing

Pleuro- (Gr.) $\pi \lambda \varepsilon v \rho \alpha ́$, rib, flank

Ploca (Gr.) $\pi \lambda$ oкฑ́, web

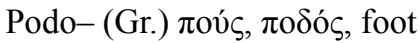

Pogon (Gr.) $\pi \omega ́ \gamma \omega v$, beard

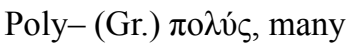

Proter- (Gr.) $\pi \rho{ } \tau \varepsilon \rho \circ \varsigma$, before, in front

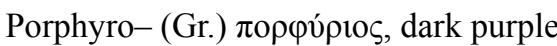

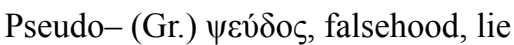

Pulvin-(L.) pulvinus, cushion, pillow

Ptyche (Gr.) $\pi \tau v \chi \eta ́, \pi \tau v \xi \xi$ leaf, plate, fold 


\section{$\mathbf{R}$}

Radio (L.) radio, to shine

Raphi- (Gr.) ṕ $\alpha \varphi \eta ́$, needle

Restis (L.) restis, rope, cord

$\mathbf{S}$

Saccus (L.) saccus, bag

Sarcina (L.) sarcina, bundle

Schizo-(Gr.) $\sigma \chi i \zeta \omega$, to split

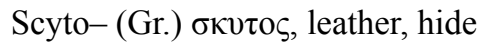

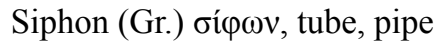

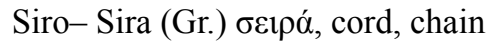

Spelae-(Gr.) $\sigma \pi \eta ́ \lambda \alpha \iota v$, grotto, cave

Sperm- (Gr.) $\sigma \pi \varepsilon \dot{\rho} \mu \alpha$, seed

\section{$\mathbf{T}$}



Tetra-(Gr.) $\tau \varepsilon \tau \rho \alpha-$, four

Thalpo-(Gr.) $\theta \alpha \dot{\lambda} \pi \mathrm{o} \varsigma$, warmth, heat

Thamn- (Gr.) $\theta$ á $\mu v o \varsigma$, bush, shrub

Thece (Gr.) $\theta \dot{\eta} \kappa \eta$, (L.) theca, case, box, chest

Thermo-(Gr.) $\theta \varepsilon \rho \mu o ́ s$, hot, warm

Thio (Gr.) $\theta \varepsilon ı v, \theta \varepsilon \dot{\varepsilon}$ iov. sulfur

\section{$\mathbf{X}$}

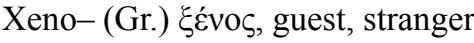

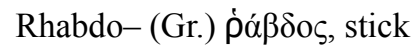

Rivularia (L.) rivulus, brook

Rubidi-(L.) rubidus, red

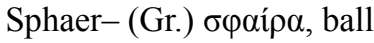

Spir- (Gr.) $\sigma \pi \varepsilon i ́ p \alpha$, (L.) spira, coil

Stauroma- (Gr.) $\sigma \tau \alpha v ́ \rho \omega \mu \alpha$, palisade

Sticho-(Gr.) $\sigma \tau i \xi \xi, \sigma \tau i ́ \chi 0 \varsigma$, row, line

Stylon (Gr.) $\sigma \tau u ́ \lambda o \varsigma$, pillar

Sym-, Syn- (Gr.) ovv, along with, together with

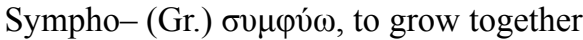

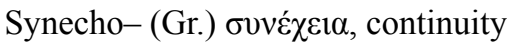

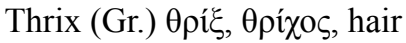

Tholos (Gr.) $\theta 0 \lambda$ ós, mud, dirt

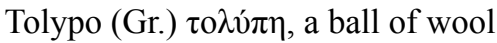

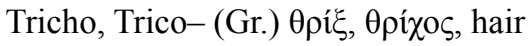

Trypo-(Gr.) $\tau \rho v ́ \pi \eta$, hole



(C) Czech Phycological Society (2011)

Recieved Sept 2010

Accepted Dec 2010 